\title{
TOURISM, LOCAL ECONOMIC DEVELOPMENT AND INCLUSION: EVIDENCE FROM OVERSTRAND LOCAL MUNICIPALITY, SOUTH AFRICA
}

\author{
Christian M. ROGERSON \\ School of Tourism \& Hospitality, College of Business and Economics, University of \\ Johannesburg, Bunting Road, Johannesburg, South Africa, email: crogerson@uj.ac.za \\ Jayne M. ROGERSON* \\ School of Tourism \& Hospitality, College of Business and Economics, University of \\ Johannesburg, Bunting Road, Johannesburg, South Africa, email: jayner@uj.ac.za
}

\begin{abstract}
Citation: ROGERSON, C.M., \& ROGERSON J.M. (2019). TOURISM, LOCAL ECONOMIC DEVELOPMENT AND INCLUSION: EVIDENCE FROM OVERSTRAND LOCAL MUNICIPALITY, SOUTH AFRICA. GeoJournal of Tourism and Geosites, 25(2), 293-308. https://doi.org/10.30892/gtg.25202-360
\end{abstract}

\begin{abstract}
A critical focus within the growing scholarship around tourism development and planning is that of tourism and local economic development (LED) planning. This paper investigates the nexus of tourism and LED planning in South Africa. Arguably, South Africa provides fertile territory for exploring this relationship because of the national importance of tourism for the economy as a whole and of a policy commitment by national government to the support of sub-national development planning. Evidence is presented from the Overstrand Local Municipality in the Western Cape, one of many small towns where tourism is a critical local economic driver. The evidence shows that tourism expansion can contribute to enhanced growth of the local economy as well as job creation for local communities. This said, the existing ownership structure of the local tourism economy is massively weighted to white entrepreneurs such that the local tourism economy cannot be described as inclusive.
\end{abstract}

Key words: local economic development, inclusive tourism, transformation, black entrepreneurs, Overstrand local municipality

\section{INTRODUCTION}

Over the past 40 years a noticeable international trend is the move away from centrally-driven approaches for economic development undertaken by national governments and their replacement by an array of local or 'place-based' development strategies initiated by sub-national tiers of government (Pike et al., 2006; Rogerson \& Rogerson, 2010; Pike et al., 2011, 2014; Rogerson, 2014; Pike et al., 2015; Rodriguez-Pose \&

\footnotetext{
* Corresponding author
} 
Wilkie, 2015). In particular, the practice of local economic development (LED) emerges as an increasingly common feature of international development planning, particularly in the context of trends towards decentralization - the deliberate transfer of resources away from central state institutions - and of changing structures of government and governance (Rodriguez-Pose \& Tijmstra, 2007; 2009). In a turbulent changing environment for development planning it is argued there is an increasingly significant role for sub-national authorities, such as local governments, in territorial planning for local development and for attaining goals of economic 'inclusion' (Rodriguez-Pose \& Wilkie, 2015, 2017). Although the precise meaning of the term is contested an 'inclusive' economy is defined as one that "expands opportunities for more broadly shared prosperity, especially for those facing the greatest barriers to advancing their well-being" (Benner et al., 2018: 6).

Arguably, sub-national tiers of government are gaining power and capabilities "to design and implement contextually tailored economic development strategies that reflect local socio-economic and institutional characteristics, conditions and realities" (Rodriguez-Pose \& Wilkie, 2017: 151). This trend is significant as it is apparent that the "new capacity of subnational authorities to devise and implement territorially oriented approaches to development represents an important opportunity for regions and localities to mobilize their full economic potential" (Rodriguez-Pose \& Wilkie 2017: 153). In many parts of the global North (as well as an increasing number of destinations in the global South) one popular focus for LED planning is tourism promotion (Butler \& Rogerson, 2016). Agarwal et al. (2000: 252) observed as far back as 2000 that "tourism is widely recognised as an instrument of local economic development". Currently, in the global South much policy attention surrounds the pro-poor credentials of tourism thus giving it often a significant role in strategies for poverty alleviation (Saarinen et al., 2013; Saarinen \& Rogerson, 2014). Arguably, as pointed out by Saarinen et al., (2017) a critical focus within the growing scholarship around geographies of tourism development and planning is that of tourism and local economic development planning. Further, there is a parallel surge of writings and concern about the 'inclusiveness' of expanding tourism economies and destinations (Butler \& Rogerson, 2016; Bakker \& Messerli, 2017; Hampton et al., 2018; Scheyvens \& Biddulph, 2018; UNWTO, 2018).

South Africa represents one of the most well - researched countries in the global South in terms of the policy and practices of LED (Nel \& Rogerson, 2005; Rogerson, 2006, 2007a, 2010, 2014; Nel \& Rogerson, 2016; Rogerson \& Nel, 2016; Rogerson, 2018a, 2019). As argued by Nel and Rogerson (2005) for much of the period of South Africa's democracy since 1994 LED planning has been undertaken, with varying degrees of commitment, and anchored on the defined principle of 'developmental local government' which was introduced in 1998. In terms of the country's national Constitution all local authorities are mandated to implement Local Economic Development (LED) strategies which in most cases take on a pro-poor focus with the exception of South Africa's metropolitan areas where market-based approaches are more in evidence (Rogerson, 2010; Nel \& Rogerson, 2016; Rogerson, 2018b). Given the apartheid legacy of inequality and racially-structured economic exclusion (World Bank, 2018) the attainment of more inclusive pathways of development is prioritised increasingly in LED policy and practice. Over the past nearly 20 years, with varying measures of success and different degrees of commitment, most South African local governments attempted to undertake LED and embracing tourism promotion as one strategic intervention (Nel \& Rogerson, 2016). In certain cases, however, local governments pass on the LED implementation mandate to local development agencies, many of which are engaged with the tourism sector (Lawrence \& Rogerson, 2018, 2019). 
Tourism, Local Economic Development and Inclusion:

Evidence from Overstrand Local Municipality, South Africa

Overall, a recent national survey undertaken of LED strategies pursued across all the country's municipal authorities showed that the tourism sector is seen as a potential driver for achieving the objectives of local economic development (Rogerson \& Nel, 2016). Indeed, across South Africa as a whole a remarkable $87 \%$ of all local authorities were targeting tourism as a potential economic engine of local development (Nel \& Rogerson, 2016). Tourism is a particular focus for development promotion in many small town municipalities of South Africa (Binns \& Nel, 2002; Rogerson, 2002a, 2002b; Marais, 2004; Donaldson, 2007; Ferreira, 2007; Nel \& Rogerson, 2007; Rogerson, 2007a; Halseth \& Meikeljohn 2009; Donaldson \& Marais, 2012; Rogerson \& Rogerson, 2014; Rogerson \& Harmer, 2015; Rogerson, 2016; Harmer \& Rogerson, 2016; Irvine et al., 2016; Donaldson, 2018; Kontsiwe, 2018; Van der Merwe \& Rogerson, 2018). For national government a major policy priority is to foster a more inclusive tourism economy by fostering the expanded participation of black tourism entrepreneurs (Department of Tourism, 2018a, 2018b). It is against this backdrop that the objective in this paper is to investigate the specific characteristics of tourism development and the role assumed by tourism as part of LED planning in one small town coastal municipality in South Africa's Western Cape province. Three sections of discussion follow. First, is a brief sketch of the case study area and a review of methodology and sources. This is followed by a detailed analysis of the key features and challenges of the Overstrand tourism economy. The third section focuses specifically on the question of how 'inclusive' is the Overstrand tourism economy both in relation to local planning objectives for inclusive development as well as wider national government initiatives for broadening the involvement in the tourism economy of South Africa's disadvantaged 'non-White' communities under apartheid.

\section{CASE STUDY AND METHODS}

The Overstrand Local Municipality is situated south east of Cape Town in Western Cape province (Figure 1). According to the 2011 census the recorded population of the Overstrand was 80432 with the largest town being that of the coastal community of Hermanus. The current estimates suggest that by 2017 the population had grown to 91190 in total (Western Cape Government, 2017). In terms of racial composition, the most recent data shows 43 percent of the population as African (black), 29 percent as Coloured and 28 percent white. The fastest growth is amongst the African community mainly as a result of expanding rates of in-migration from poverty-stricken areas of Eastern Cape province (Overstrand Local Municipality, 2018a, 2018b). Geographically the Overstrand region is bordered by the Atlantic Ocean. Accordingly, tourism development in this local municipality is part of the 'blue economy' and wider national government initiatives for expanding coastal and marine tourism in South Africa (Rogerson \& Rogerson, 2019).

Within the Overstrand Municipality are several tourism destinations including Hermanus, Kleinmond, Betty's Bay, Stanford and Gansbaai. The area encompasses a range of tourism assets including wine farms in the Hemel-en-Aarde Valley and the Walker Bay region, numerous natural protected areas which provide hiking and camping opportunities as well as a variety of marine activities most notably whale viewing and cage diving at Gansbaai with great white sharks. The urgency for LED planning in this municipality to become more 'inclusive' was underlined during 2018 by mass civil disturbances part of which was triggered by the absence of economic livelihood opportunities. Protests were led by poor residents from the area's black (Zwelihle) and coloured townships (Hawston), which were consolidated under apartheid planning. Underpinnings of the civil disturbances are the absence of affordable housing and (relatively) high levels of local unemployment, estimated as 23 percent for Overstrand as a whole but with youth unemployment rates exceeding 30 percent (Steyn, 2018a, 2018b, 2018c, 2018d, 2018e, 2018f). 


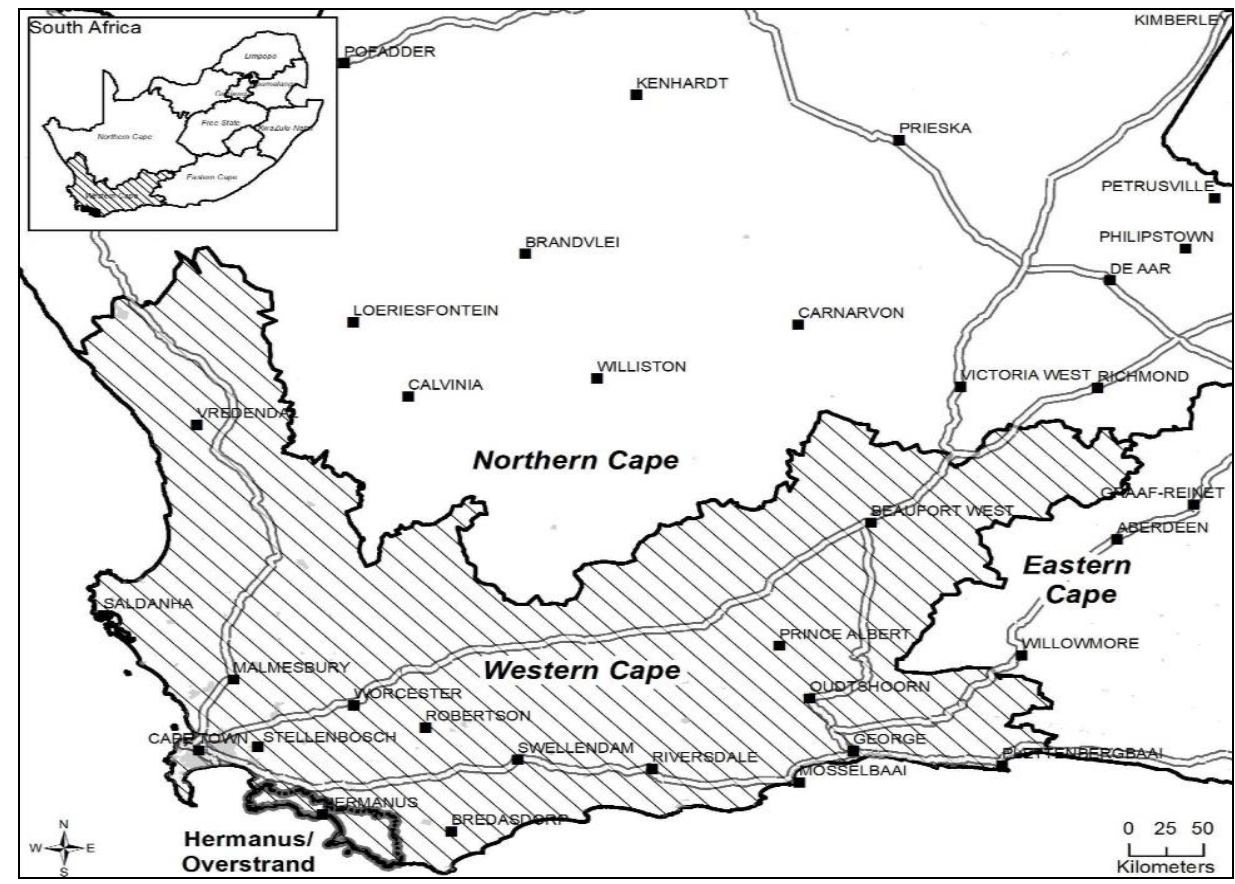

Figure 1. Overstrand Local Municipality

In researching the local economy and issues pertaining to tourism reliance upon primary source material was necessary as economic development issues relating to the Overstrand region in general have not been the focus of much scholarly attention with the exception of works by Findlay (1997) on whale watchers and McKay (2017) on shark-cage diving at Gansbaai. At the outset an extensive documentary search was undertaken for relevant planning reports, the local Integrated Development Plan and existing studies on tourism in the municipality. In addition, relevant data concerning the changing tourism economy was accessed both through these reports and the (unpublished) IHS Global Insight data base which has been utilised successfully in other recent South African research on tourism (Rogerson, 2018).

The key local planning documents that inform this discussion are those relating to local development in the Overstrand municipality, most importantly the Integrated Development Plan (IDP) (Overstrand Local Municipality, 2012, 2014, 2018a, 2018b). Other relevant individual reports were accessed relating to proposed projects in tourism and of related developments including for aquaculture projects. Further primary material dealing with contemporary issues was secured by working through The Village News, the local Overstrand newspaper. The findings from these documentary sources are supplemented by and triangulated with a set of qualitative semi-structured key interviews which were undertaken with municipal officials responsible for the local tourism economy, tourism promotion and marketing.

In addition, further interviews were conducted with members of the local communities (including an established black tourism entrepreneur) as well as several key private sector stakeholders in the local tourism economy including the leader of a local think-tank (initiated following the protest actions) to improve the local tourism economy. For ethical reasons the names of our interview respondents are not disclosed. 


\section{THE OVERSTRAND TOURISM ECONOMY: STRUCTURE AND ASSETS}

A profile of the contemporary tourism economy of the Overstrand can be obtained through an analysis of the local level data which is extracted from the data base of IHS Global Insight. The available information for 2001-2015 is supplemented by the findings drawn from a number of recent investigations on the state of the local tourism economy which have been prepared for the local municipality (PricewaterhouseCoopers, 2010; Lloyd, 2018) as well as from material sourced from our stakeholder interviews. The major characteristics of the local tourism economy are presented and analysed on Tables 1-4.

Table 1. Overstrand Municipality: Purpose of Trip 2001-2015 (Source: IHS Global Insight data)

\begin{tabular}{|l|c|c|c|c|c|c|c|c|c|}
\hline & 2001 & $\%$ & LQ & 2006 & $\%$ & LQ & 2015 & $\%$ & LQ \\
\hline Leisure & 73653 & 59.3 & 2.72 & 96515 & 60.2 & 3.41 & 119292 & 55.6 & 3.02 \\
\hline Business & 9830 & 7.9 & 0.79 & 12961 & 8.1 & 0.80 & 15968 & 7.4 & 0.65 \\
\hline VFR & 34359 & 27.7 & 0.51 & 46820 & 29.2 & 0.46 & 75285 & 35.1 & 0.57 \\
\hline Other & 6345 & 5.1 & 0.36 & 3997 & 2.5 & 0.27 & 3971 & 1.9 & 0.21 \\
\hline Total & 124187 & 100.0 & & 160292 & 100.0 & & 214517 & 100.0 & \\
\hline
\end{tabular}

Table 1 reveals the growth of Overstrand as a tourism destination with the near doubling in total number of tourist trips recorded in the period 2001 and 2015. This said it is estimated that 81 percent of tourist trips to Overstrand are for a one night stay only (Steyn, 2018g). In terms of purpose of visit it is revealed that the Overstrand tourism economy is dominated overwhelmingly by leisure trips which accounted for 60 percent of all tourist trips in 2006. Between 2006 and 2015 a relative decline in the numbers of leisure trips is evidenced. During 2018 leisure visits to the Overstrand were boosted by the water crisis in Cape Town; in one municipal report it was remarked of 2018 trips that "there was a component of visitors who see the Cape Whale Coast as a shortdistance local destination with the prospect of taking a bath and doing laundry high on the agenda" (Overstrand Local Municipality, 2018b: 22). Since 2001 it is apparent that VFR tourism has expanded in significance in the Overstrand. Nevertheless, the share of VFR travel which is recorded for the Overstrand is far below that of the country as a whole. Business tourism is of only minor significance in the contemporary Overstrand tourism economy, albeit there are a number of initiatives seeking to boost this segment which are associated with the establishment of several small conference venues at local hotels and in particular at the upmarket Arabella Golf Estate (Lloyd, 2018).

Another dimension of conference tourism is The Grail Centre at Kleinmond which is run by a faith-based organisation and targeted at the market of nongovernment as well as non-profit organisations. The calculation of location quotients shows clearly that Overstrand tourism economy is massively concentrated around leisure tourism with business and VFR travel of minimal significance. Across the different aspects of leisure tourism the interviewees asserted that the strength of the Overstrand region and especially of Hermanus was as 'a family-oriented' destination as compared to an 'aspirational destination' such as Franschhoek a fashionable food and wine destination situated in the heart of the Cape Winelands. The Overstrand IDP (2012: 85) acknowledges also the need to focus on enhancement of recreational facilities for the youth and family activities which it considered could be achieved "through development of harbours and caravan sites with tourism concentrations".

Tables 2 and 3 unpack the data by origin of visit, whether domestic or international. Table 2 focuses on trips and Table 3 on bednights. Table 2 shows the dominance of domestic tourists in the Overstrand economy which represents the 
continuation of a long history of the evolution of Hermanus as a domestic tourism resort (Lloyd, 2018). It is observed, however, that across the period 2001-2015 there is a relative reduction in the overall share of domestic as opposed to international trips from 80.1 percent in 2001 to 78.3 percent by 2015. This is a general reflection of the downturn in domestic travel since 2010 accompanying a downturn in the national economy. According to one report (Steyn, 2018g), most domestic visitors are either from the Western Cape (58\%) or Gauteng (17\%) which is South Africa's economic heartland. In terms of location quotients it is revealed that Overstrand emerges as relatively strong for international as against domestic travel. Unlike the national picture of international tourism which is dominated by regional visitors from sub-Saharan Africa the cohort of international tourists to Hermanus is comprised mostly of long-haul international travellers. In the research undertaken by PricewaterhouseCoopers (2010: 25) it was recorded that the "majority of international visitors come from Europe and the United Kingdom". More recent information points to the leading three international source markets are Germany (29 \%), the United Kingdom (25\%) and the United States (6\%) (Steyn, 2018g). The Netherlands is further cited as a significant source market. Tour groups from China are also observed as growing in numbers particularly in Hermanus (but not other parts of the Overstrand) and most recently, the interviewees from the local destination marketing organisation have observed an upturn in visitors from Israel.

Table 2. Overstrand Municipality: Origin of Trip 2001-2015 (Source: IHS Global Insight data)

\begin{tabular}{|l|c|c|c|c|c|c|c|c|c|}
\hline & 2001 & $\%$ & LQ & 2006 & $\%$ & LQ & 2015 & $\%$ & LQ \\
\hline Domestic & 99478 & 80.1 & 0.96 & 126364 & 78.8 & 0.94 & 167915 & 78.3 & 0.98 \\
\hline International & 24709 & 19.9 & 1.19 & 33928 & 21.2 & 1.25 & 46602 & 21.7 & 1.05 \\
\hline Total & 124187 & 100.0 & & 160292 & 100.0 & & 214517 & 100.0 & \\
\hline
\end{tabular}

Table 3. Overstrand Municipality: Bednights by Trip Origin 2001-2015 (Source: IHS Global Insight data)

\begin{tabular}{|l|c|c|c|c|c|c|c|c|c|}
\hline & 2001 & $\%$ & LQ & 2006 & $\%$ & LQ & 2015 & $\%$ & LQ \\
\hline Domestic & 568189 & 62.5 & 0.86 & 834825 & 61.7 & 0.81 & 626569 & 50.9 & 0.81 \\
\hline International & 341586 & 37.5 & 1.34 & 519280 & 38.3 & 1.60 & 603463 & 49.1 & 1.30 \\
\hline Total & 909775 & 100.0 & & 1354105 & 100.0 & & 1230032 & 100.0 & \\
\hline
\end{tabular}

The rising significance of international tourism in the local Hermanus economy is particularly evidenced on Table 3 which focuses on bednight data. It is disclosed that the share of bednights accounted for by international as opposed to domestic tourists is considerably higher than that recorded by trip data demonstrating their longer average stay. By 2015 of the total estimated bednights (commercial and non-commercial) of 1.23 million almost half were accounted for by international visitors. The computation of location quotients shows clearly the significance of international tourists in terms of bednights in the area's range of commercial accommodation establishments - hotels, bed and breakfasts, guest houses, backpackers as well as a surge in Airbnb offerings. In interviews it was observed that the established larger accommodation establishments currently are seeking municipal intervention in order to curtail the continued growth of 'illegal' non-registered accommodation providers on grounds that such establishments function without the appropriate payment of local rates and taxes. Larger businesses consider that the municipality is not enforcing by-laws regarding guesthouses and (almost exclusively white-owned) Airbnb establishments such that bednights are 'taken away' from formal establishments with knock-on effects for local revenue and taxes. Key Overstrand tourism assets surround the area's spectacular natural beauty (sea vistas, 
beaches, wine farms and biodiversity in terms of fynbos) and in particular that Hermanus represents one of the world's best locations for land-based whale-watching. In addition, Gansbaai is the most important base for shark-cage diving which is a popular 'bucketlist' item for many long-haul international tourists particularly from Europe and North America. Other adventure tourism activities in the Hermanus area include canopy tours, ziplining, parasailing, sand boarding, tubing and quad biking.

The demarcation of hiking trails and cycling pathways are further additions to the locality's tourism assets (Anon., no date; Withers Environmental Consultants and Urban Dynamics, Western Cape, 2017). Of particular significance is an ecotourism trail that traverses the Kogelberg Nature Reserve and includes the establishment of a network of (eco-) cabins for hikers (Anon., no date). Another recent initiative launched in December 2018 - that impacts Hermanus is Cape Cycle Routes, which is a project of the Western Cape Government to expand the provincial tourism sector and create jobs by promoting cycling tourism. Overall, in the opinion of interviewee Hermanus deserves the title of 'adventure tourism capital' of South Africa.

Table 4. Main Festivals in the Overstrand Area

(Source: PricewaterhouseCoopers 2010: 19 and Overstrand Local Municipality, 2012: 87)

\begin{tabular}{|l|l|l|l|}
\hline \multicolumn{1}{|c|}{ Month } & \multicolumn{1}{c|}{ Event } & \multicolumn{1}{c|}{ Type } & \multicolumn{1}{c|}{ Location } \\
\hline January & Blue Flag Festival & Eco-attraction & Hermanus \\
\hline January & Total Sports Challenge & Adventure/Sport & Kleinmond \\
\hline March & Cape Epic Mountain Bike Race & Adventure/Sport & Hermanus/Kleinmond \\
\hline April & Hermanus Stanford Canoe race & Adventure/Sport & Hermanus/Stanford \\
\hline April & Hermanus Harbour Museum Seafood & Cultural/Food & Hermanus \\
\hline July & Hermanus Food \& Wine Festival & Cultural/Food & Hermanus \\
\hline August & Kalfie Fees & Cultural/Food & Hermanus \\
\hline September & Hermanus Whale Festival & Ecotourism & Hermanus \\
\hline September & Hermanus Half Marathon & Adventure/Sport & Hermanus \\
\hline October & Stanford Birding Festival & Ecotourism & Stanford \\
\hline November & Festival of the Gans & Ecotourism & Gansbaai \\
\hline December & Hawston Sea Festival & Cultural/Food & Hawston \\
\hline
\end{tabular}

Culinary tourism is rising in importance as a result of the opening of a number of fine dining establishments particularly in the Hemel-en-Aarde Valley and Wine Route which it was stated recently had overtaken Paarl to be now the fourth most important wine route in South Africa. The respondents stressed that Hemel-en-Aarde is 'the Pinot Noir capital' of South Africa and was the only wine route with such a strong association to a particular type of wine. The growth of second homes and retirement communities also is noted as significant elements in the make-up of the Overstrand tourism economy. One of the least developed niches in the Overstrand tourism economy is cultural tourism which has prompted a number of initiatives to collect local stories and histories to build this focus (Lloyd, 2018). Cultural heritage potential exists in archaeological features of the Fernkloof Nature Reserve (Withers Environmental Consultants and Urban Dynamics, Western Cape, 2017). Major heritage potential exists in the Overstrand area, including the towns of Hermanus and Stanford but most importantly around Gansbaai. At Danger Point close to the town of Gansbaai there is the memorial to the sinking of the HMS Birkenhead troopship in 1852. This site is of international significance in terms of maritime heritage for it being the first maritime protocol that when abandoning ship the convention is of 'women and children first' (now named the Birkenhead Drill). A number of attempts have been undertaken to launch township tours in Zwelihle albeit these enjoy 
limited success mainly because of the lack of any distinctiveness of a local township tour there as compared to, for example, Cape Town townships such as Khayelitsha or Langa.

At Hawston the potential is observed for the growth of church tourism and particularly so as one church has the Bible's Ten Commandments inscribed in High Dutch.

The regular hosting of a series of festivals and events throughout the year is critical also for boosting tourist spending in the Overstrand as well as day visitors drawn mainly from Cape Town (Table 4). Amongst the most significant festivals is the annual Whale Festival (2018 in its 27th year of operation) which is held in late September in order to celebrate the arrival from Antarctica of breeding communities of Southern Right whales in Walker Bay. Other festivals include the Fynarts Festival during June, Kalfiefees during August celebrating Afrikaans culture through drama and theatre, the Hermanus Wine and Food festival (held in October during 2018), as well as a myriad of smaller week-end sporting and cultural events in the towns and surrounding wineries (Pricewaterhouse Coopers, 2010). Our respondents noted that beyond the Whale Festival the most impactful is Kalfiefees. By contrast, the June Fynarts Festival was described by one interviewee simply as "a wonderful way for locals to get together with a glass of wine". The caveat was added, however, that over a longer period the potential existed for growth of this festival and to bring in tourism to Hermanus. The vital importance of events to Hermanus tourism is endangered by the 2018 community protest actions which caused blocking of the main R43 access road from Cape Town into Hermanus.

During early November 2018 after residents again blocked the R43 road into Hermanus with burning tyres and rocks the organisers of the Wines2Whales Mountain Bike Race decided to change the route of the last leg of the race to exclude Hermanus. The consequence was a dramatic downturn in local business with the loss of thousands of tourists, mountain bikers, support teams and spectators not visiting Hermanus (Steyn, 2018h). Looking forward, a further threat to Hermanus tourism is that the 2019 Cape Epic cycling event, one of the largest in the world, which is due to come to Hermanus for two days in March 2019 but is under threat because of safety concerns.

Overall, the key respondents reiterated that whilst Hermanus traditional strength was as a 'family' friendly tourism destination it was undoubtedly at present growing its reputation for its culinary offerings as well as for adventure tourism. Several challenges were raised for the continued health and development of the Overstrand tourism economy. The 2018 community protests following the negative knock-on effects for Hermanus of the droughts and of Cape Town's water crisis (which impacted international bookings in the Overstrand) had tarnished the image of the area, particularly as a 'familyfriendly' tourism destination. The major promotional initiatives for the Overstrand in terms of expenditure were led by the local private sector which it was stated spends "around R2O million in marketing Hermanus and surrounds as compared to the pittance spent by the municipality". The vision of the marketing strategy for the Cape Whale Coast is for it "to be one of the top five preferred tourist destinations in South Africa” (Lloyd, 2018a: 4). In terms of implementation the central aims of the marketing strategy include, inter alia, the attraction of more return visitors, encouraging longerstays, the promotion of a calendar of events/festivals, and ensuring "the efficient utilisation of resources in order to deliver against the tourism strategy" (Lloyd, 2018: 3).

In stakeholder interviews critical issues were discussed of inappropriately targeted marketing and of the failure of the local destination marketing organisation to aggressively promote Hermanus (as compared to other areas of the Western Cape) to attract the attention of visiting international travel writers. For example, in terms of overseas marketing Hermanus had missed out on international road shows recently 
undertaken to India and Australia. One respondent stated that the local destination marketing organisation for Hermanus tourism "does not apply the pressure to get the people who count here" in terms of visiting VIPs. In support was cited the example of missing out opportunities to connect with 80 press agents from the United Kingdom visiting the Western Cape. In addition, key stakeholders reflected that Hermanus also was not maximising potential benefits from initiatives and marketing undertaken by WESGRO, the provincial marketing agency. It was argued that much greater effort in terms of marketing and signage could be given to the promotion and boosting of the Cape Whale Coast route and of the products linked to it. Respondents pointed to the success of the Midlands Meander in KwaZulu-Natal (see Lourens, 2007) as compared to the limited impact so far recorded of similar route tourism initiatives for the Overstrand.

Notwithstanding these issues, stakeholders argued that the major accommodation providers in the town operate at almost full occupancies particularly in peak season. High levels of occupancy are recorded not only at the top-end accommodation service establishments in peak season but also in budget accommodation. Certain municipal caravan parks in Overstrand, such as Gansbaai reported over 90 percent occupancy during the 2017 Christmas-New Year seasonal peak (Overstrand Local Municipality, 2018b: 15). Overall, it was recorded that for this period "camping at Overstrand camping resorts did well with a 90\% occupancy rate" (Overstrand Local Municipality, 2018b: 16). This said, existing research on the nature of Overstrand tourism as well as the findings from our stakeholder interviews confirm that the core problem is that of seasonality which negatively impacts the local tourism economy. In particular during the months of May, June and July the local tourism economy experiences a major downturn in terms of tourist arrivals and accommodation bookings. The Overstrand IDP notes that one of the major challenges for the implementation of the municipal LED strategy is "a strong seasonal economy" (Overstrand Local Municipality, 2012: 22). The hosting of a number of festivals in these months has only partially addressed this issue which during 2018 was exacerbated by the community protest actions. One interviewee suggested the need to refocus some of the marketing initiatives undertaken by the local destination marketing organisation. One respondent argued that there was "no point" in marketing Hermanus in season as there "are no 400 or 500 bedrooms to fill". It was argued that the feeling was widespread that for tourism promotion Hermanus had become 'complacent' and that there now was a need for a long-term marketing strategy for the region. One suggestion to address the seasonality issue was for the possible innovation of a winter pass for Hermanus which might offer discounts to attract out of season visitors along the lines of the observed success of similar initiatives recently undertaken by other South African destinations. The need for Overstrand to become a year long destination is acknowledged in the municipal IDP documentation which states as follows: "Over the years through many creative and innovative efforts in collaboration with the private sector the ever problematic and slow economic drive of the bane of seasonality has been a priority" (Overstrand Local Municipality, 2018a: 67).

Table 5. Overstrand Municipality: Total Tourism Spend (R'ooos Current Prices) (Source: IHS Global Insight data)

\begin{tabular}{|c|c|c|}
\hline Year & R'ooos & \% RSA \\
\hline 2001 & 553359 & 0.07 \\
\hline 2006 & 927876 & 0.07 \\
\hline 2015 & 1877789 & 0.08 \\
\hline
\end{tabular}


Table 5 shows computed estimated total tourism spend for the Overstrand municipality. In the national context Overstrand represents an estimated share of close to 1 percent. Overall, by 2015 Overstrand was $11^{\text {th }}$ ranked in terms of South African municipalities for numbers of leisure trips (1.6\% national total), $17^{\text {th }}$ in terms of international trips (0.9 percent of national total) and $16^{\text {th }}$ most important municipality in terms of national tourism spend (o.8 percent). In terms of estimated contribution of total spend to local GDP for Overstrand it is calculated that at least 50 percent is accounted for by tourism which places Overstrand amongst the top 10 most tourism-dependent municipalities in South Africa. Arguably, as the lead sector in the Overstrand economy tourism is the main driver for the growth of local employment opportunities. The largest individual employer in the area, however, is local government and followed by Abagold, which is a private sector enterprise engaged in aquaculture which is founded on the cleanliness of the local seawater. The rising significance of aquaculture is a distinctive facet of the Overstrand local economy (Overstrand Aquaculture Consortium, 2008).

The aquaculture sector began to develop in the late 1990 s and headed by "entrepreneurs and private companies with limited support from government institutions" (Overstrand Aquaculture Consortium, 2008: 9). Fifteen years later a complete value chain, from hatcheries to export channels has been consolidated such that the local aqua-hub produces export quality world-class products. Indeed, aquaculture represents "one of the fastest growing industries in the area" and is significant locally as it "helped mitigate job losses in the agriculture sector" (Overstrand Local Municipality, 2018a: 67). Manufacturing activity in Overstrand is confined mainly to abalone processing and a number of establishments which are engaged in the production of wine, craft beer and gins. All these manufacturing operations have synergies with the local tourism economy in terms of offering factory tours and alcohol tastings. Abalone tours as well as visits to craft beer breweries, craft gin producers as well as the region's high quality wine farms are an important aspect of the local tourism product.

Overall, for the Overstrand Local Municipality, tourism is a critical sector of the 'blue economy' alongside the illicit 'mining' as well as legal farming of abalone which drive the local economy and in particular of Hermanus its major tourism hub. The critical role assumed by tourism in Overstrand economic development is manifest most clearly in the municipal Integrated Development Plan (IDP). The IDP review strongly endorses the promotion of economic and social development and aligns its IDP objectives to those of the global Sustainable Development Goals. Successful tourism promotion is viewed as linked to several SDGs including 1 to end poverty, 3 to ensure healthy lives and promote well-being, 5 to achieve gender equality and most importantly SDG 8 "to promote sustained inclusive and sustainable economic growth, full and productive employment and work for all" (Overstrand Local Municipality, 2018a: 170-171). The next section turns to analyse the extent to which the tourism economy in Overstrand is inclusive.

\section{INCLUSIVE TOURISM IN THE OVERSTRAND}

National government in South Africa has been engaged with several initiatives that are seeking to redress the racial patterns of ownership and of entrepreneurship in the tourism sector. Over the two past decades national government introduced a range of initiatives to deepen opportunities for involvement by small, medium and microenterprises (SMMEs) in tourism as well as to support wider objectives of transformation and of inclusion (Department of Tourism, 2018a, 2018b). These interventions have been geared to address the particular challenges and needs of black owned SMMEs in tourism. Of particular note has been the activities of the Tourism Enterprise 
Tourism, Local Economic Development and Inclusion:

Evidence from Overstrand Local Municipality, South Africa

Partnership (formerly the Tourism Enterprise Programme) which provided SMMEs with skills development, market access and business support advice (Rogerson, 2007b). The Department of Tourism launched its own dedicated SMME support programmes with the goal of ensuring the sustainable development and growth of tourism enterprises that facilitates inclusive participation, job creation as well as strengthening the competitiveness of tourism destinations (Department of Tourism, 2018a). The programme accords acknowledgement that "effective enterprise support" would allow for the development of "black tourism related businesses" (Department of Tourism, 2018a: 31). Other innovative interventions have been the establishment of tourism business incubators to support start-up entrepreneurs (Rogerson, 2017).

Table 6. Major Accommodation Service Providers in the Overstrand

\begin{tabular}{|c|c|c|c|}
\hline Name & Location & Ownership & Characteristics \\
\hline Arabella Hotel and Spa & Kleinmond & $\begin{array}{l}\text { African Pride - } \\
\text { Protea Marriott }\end{array}$ & $\begin{array}{l}\text { Four/Five Star, } 145 \text { rooms. Golf } \\
\text { course and spa }\end{array}$ \\
\hline The Grail Centre & Kleinmond & $\begin{array}{l}\text { Non-Profit, Faith- } \\
\text { based organisation }\end{array}$ & 13 self-contained cottages \\
\hline Windsor Hotel & Hermanus & Independently Owned & $\begin{array}{l}\text { Three star, } 70 \text { bedrooms. Built on } \\
\text { original site of the Sanatorium }\end{array}$ \\
\hline Birkenhead House & Hermanus & $\begin{array}{l}\text { Owned by Liz Biden } \\
\text { and part of her Royal } \\
\text { Portfolio of } 5 \text { hotels }\end{array}$ & Boutique Five star, 11 luxury rooms \\
\hline The Marine & Hermanus & $\begin{array}{l}\text { Owned by Liz McGrath } \\
\text { Collection of } 3 \text { hotels }\end{array}$ & Boutique Five star, 40 rooms \\
\hline Misty Waves Hotel & Hermanus & Privately owned & Four Star, 32 guest rooms \\
\hline Harbour House & Hermanus & Privately owned & Four star,48 rooms \\
\hline Baleens Hotel & Hermanus & Privately owned & 21 rooms \\
\hline The Whale Coast Hotel & Hermanus & De Chatillion Collection & Four stars, 15 rooms \\
\hline $\begin{array}{l}\text { Marine Square Luxury } \\
\text { Holiday Suites }\end{array}$ & Hermanus & Privately owned & Five star, 10 self catering suites \\
\hline Hermanus Esplanade & Hermanus & Privately owned & 2 star, 25 self catering units \\
\hline Auberge Burgundy Guest House & Hermanus & Privately owned & Five star guest house, 19 rooms \\
\hline Abalone Guest Lodge & Hermanus & Privately owned & 12 rooms \\
\hline Whale Rock Luxury Lodge & Hermanus & Privately owned & 4 stars, 11 rooms \\
\hline Schulphoek House & Hermanus & Privately owned & 5 star guest house, 15 rooms \\
\hline Hermanus Boutique Guest House & Hermanus & Privately owned & 4 star, 17 rooms \\
\hline Ocean Eleven Guest house & Hermanus & Privately owned & 5 star guest house, 10 rooms \\
\hline 7 On Marine & Hermanus & Privately owned & Four star guest house, 10 suites \\
\hline Sea Villa & Pringle Bay & Privately owned & Three star, 24 rooms \\
\hline Blue Gum Country Estate & Stanford & Privately owned & 13 rooms \\
\hline Hermanus Backpackers & Hermanus & Privately owned & 10 rooms - backpacker lodge \\
\hline Zoete Inval Travellers Lodge & Hermanus & Privately owned & 10 rooms, backpacker lodge \\
\hline Kleinvlei Hermanus & Hermanus & Privately owned (?) & $\begin{array}{l}20 \text { rooms, backpackers } \\
\text { (self- catering and camping) }\end{array}$ \\
\hline Stanford Valley Guest Farm & Stanford & Privately owned & 18 units, self-catering and $\mathrm{B}$ and $\mathrm{B}$ \\
\hline Uylenvelei Retreat & Gansbaai & Privately owned & $\begin{array}{l}15 \text { rooms, self -catering and tents } \\
\text { with communal facilities }\end{array}$ \\
\hline Gansbaai Boarding Lodge & Gansbaai & Privately owned & $\begin{array}{l}13 \text { rooms, B and B and dorm } \\
\text { rooms }\end{array}$ \\
\hline $\begin{array}{l}\text { Grootbos Lodge and } \\
\text { Nature Reserve }\end{array}$ & Gansbaai & Privately owned & $\begin{array}{l}5 \text { star, } 29 \text { suites, nature related activities } \\
\text { (includes } 2 \text { villas of } 4 \text { and } 6 \text { bedrooms) }\end{array}$ \\
\hline
\end{tabular}


These incubators are viewed as key vehicles for transforming the South African tourism sector in terms of making it inclusive and accessible to new entrants. The overall goal of national government is to create a conduit for economic inclusion by building the competitiveness of tourism businesses for increased sustainable jobs and economic growth and development. The above raft of policy initiatives seek to transform tourism local economies by increasing the participation of Black entrepreneurs. However, as is the case for much of tourism in small town South Africa (particularly in areas outside of those formerly designated as Homelands), the historical development of tourism in Overstrand is almost exclusively dominated by white entrepreneurs. In several works, such as those by Tredgold (1980) and by Lee (2017), the important historical roles played by early hoteliers such as the Luyt family with their establishment and continued operations of the Marine Hotel in Hermanus. In addition, Hunt's (2017) account of the historical development of hotels in Hermanus celebrates the town's entrepreneurial citizens who transformed what was in 1915 an insignificant fishing village to become by 1947 "one of the pre-eminent sea-side holiday resorts in the country, and well-known abroad" (Hunt, 2017: 39). The commanding role assumed of white entrepreneurs in the Hermanus tourism economy continued during the apartheid period at a time when severe restrictions existed on business development by black entrepreneurs. Following the democratic transition, the ownership structure of the key components of the tourism economy has been little changed. Our analysis of the contemporary tourism economy of Hermanus indicates its 'exclusive' character in terms of ownership of key tourism assets by small corporates, independent hotel operators and a large number of tourism SMMEs operated by white entrepreneurs.

For example, Table 6 shows the major accommodation establishments in the Overstrand Local Municipality some of which are in corporate ownership as part of hotel groups and others being independent white owned small accommodation services. The local Coloured and black communities of the Overstrand area are represented in the accommodation service sector of tourism almost exclusively as workers and only minimally so as tourism entrepreneurs. Table 7 gives a summary analysis of the key findings about the contemporary Overstrand tourism economy and of its ownership profile. It is evident that the Overstrand tourism economy is not a case of national government's desire for inclusive tourism development that would incorporate marginalised groups as participants in the local tourism economy. All the interviews with key stakeholders confirmed that Overstrand tourism is exclusive with its dominance by white capital and by white SMME entrepreneurs. In accommodation services, tour services and restaurants/dining sector the record is of continued overwhelming white ownership. The fine dining country establishments and boutique offerings as well as the majority of local restaurants geared to visitors are white-owned and operated.

Across the majority of the major tour attractions from shark diving, adventure tourism or wine estate visits it is a similar pattern of white ownership of the enterprises which are associated with these attractions. As McKay (2017) shows for the shark-cage operators at Gansbaai the activity is largely dominated by white entrepreneurs.

In recent years the only exceptions are/or have been one black owned bed and breakfast establishment in Zwelihle (now closed), one young local DJ entrepreneur who is seeking to develop the entertainment industry in Zwelihle (Overstrand Local Municipality, 2018b:17), and most significantly of one established black tour operator who initiated his business in 2012. The black tour operator offers a range of tailor-made tours, fishing trips, shuttle services, township tours as well as facilitating adventure tour activities. In the interview he confirmed that overall "there are few entrepreneurs in 
Tourism, Local Economic Development and Inclusion:

Evidence from Overstrand Local Municipality, South Africa

Zwelihle" and himself the only black tour operator. This said, in the supply of local township tours there is another operator, Urban Tours, which markets opportunities to "explore township life through responsible tourism"; the enterprise is run by two local (white) women. In relation to art and craft goods, limited production was disclosed despite the fact that in Zwelihle there is a community of women sewers and at Hawston a workshop exists where disabled members of the community are engaged on crafts. The Zwelihle tours which are operated by the black tour services entrepreneur incorporate visits to some local houses, part of which are converted to display for sale of local arts and crafts. In addition, these tours seek to offer other income opportunities for local residents through walking tours that include visits to a local shebeen for tastings of traditional beer, a take away shop selling traditional foods, and at the conclusion of the tour an opportunity for visitors to enjoy a foot massage from a trained therapist in Zwelihle.

Table 7. Key Tourism Products and Inclusivity in the Overstrand Region

\begin{tabular}{|c|c|}
\hline \begin{tabular}{|c|} 
Tourism \\
Product/Asset
\end{tabular} & Ownership \\
\hline $\begin{array}{c}\text { Accommodation } \\
\text { Services }\end{array}$ & $\begin{array}{l}\text { In Hermanus are } 8 \text { hotels and over } 150 \text { bed and breakfasts, guest houses or lodges } \\
\text { as well as } 292 \text { advertised Airbnb listings (November 2018) of houses, garden } \\
\text { cottages and flats. The two hotels at the apex of the local accommodation services } \\
\text { are boutique establishments and part of two different small Western Cape } \\
\text { portfolios. All graded independent guest houses/bed and breakfast establishments } \\
\text { are located in the predominantly white residential areas. There are no Airbnb } \\
\text { listings in the residential areas of the poorer Coloured or Black communities. }\end{array}$ \\
\hline Tour Services & $\begin{array}{l}\text { Several local tour service providers offer travel services including specialist tours } \\
\text { on motor-bikes. In total Trip Advisor lists for Hermanus } 27 \text { tour companies } \\
\text { engaged with dolphin and whale watching (9), nature and wild life tours (6), scuba } \\
\text { and snorkelling (6), shark diving (5), sightseeing (5), adrenalin and extreme tours } \\
\text { (3) and boat tours (3). With one exception, there is minimal evidence of } \\
\text { involvement by black entrepreneurs in tour services as entrepreneurs. }\end{array}$ \\
\hline $\begin{array}{l}\text { Restaurants } \\
\text { /Fine Dining }\end{array}$ & $\begin{array}{l}\text { Trip Advisor lists } 96 \text { restaurants and fine dining experience in Hermanus and } \\
\text { surrounds. The apex of the food and wine experience is at the upmarket wineries } \\
\text { and boutique hotels and country restaurants which cluster in the Hemel-en- } \\
\text { Aarde valley and picturesque view sites in Hermanus town. Stanford is another } \\
\text { focal point for food tourism with } 19 \text { listed restaurants. Throughout Overstrand } \\
\text { no evidence exists of any black entrepreneurial involvement in food tourism with } \\
\text { the exception of a community-owned restaurant which has been initiated at the } \\
\text { visitor centre of the Stony Point penguin colony. }\end{array}$ \\
\hline $\begin{array}{l}\text { Tourism } \\
\text { attractions }\end{array}$ & $\begin{array}{l}\text { All the core tourism attractions of the Overstrand, including ecotourism, wine and } \\
\text { food and adventure activities are operated and owned by white entrepreneurs. } \\
\text { Conference tourism is focused on the corporate owned Arabella golf course under } \\
\text { the ownership of the African Pride Group which are part of Protea/Marriott. } \\
\text { Once again, no evidence exists of black entrepreneurial involvement. }\end{array}$ \\
\hline
\end{tabular}

\section{CONCLUSION}

The nexus of tourism and planning for local economic development is attracting a growing international scholarship. South Africa provides fertile territory for exploring this relationship because of the national importance of tourism in the economy as a whole and of a commitment to the support of sub-national development planning. In a recent diagnostic paper on the trajectory of national development the World Bank (2018) draws attention to progress made in South Africa since the advent of democracy in 1994. It cautions, however, that it is an 'incomplete transition' as the economic transition from a 
system of historical exclusion under segregation and apartheid policies remains incomplete. Accordingly, calls for promoting 'inclusive' economic development pathways are firmly on the policy agenda in South Africa, including for the tourism sector.

Across South Africa tourism is identified as a key sectoral driver for LED by the majority of the country's local authorities and particularly emphasized by many small towns. The evidence from Overstrand Local Municipality is that the growth of tourism can contribute to enhanced growth of the local economy as well as job creation for local communities. Nevertheless, it was demonstrated that ownership and entrepreneurship in the tourism sector continues a pattern which was established from the earliest period of tourism development going back to the early $20^{\text {th }}$ century in the case of Overstrand. The existing ownership structure of the local tourism economy is overwhelmingly weighted towards white entrepreneurs such that the local tourism economy cannot be described as inclusive. In addressing this historical legacy national government has enacted over the past decade a number of support initiatives which are designed to expand the participation of black entrepreneurs in growing the tourism economy. Arguably, the impact of these support measures and the challenges for making of local inclusive tourism economies merit further investigation by tourism and development scholars in South Africa.

\section{Acknowledgements}

Thanks to the National Department of Tourism that funded this research

\section{REFERENCES}

Agarwal, S., Ball, R., Shaw, G., \& Williams, A. (2000). The Geography of Tourism Production: Uneven Disciplinary Development. Tourism Geographies, 2, 241-263.

Bakker, M., \& Messerli, H. (2017). Inclusive Growth Versus Pro-Poor Growth: Implications for Tourism Development. Tourism and Hospitality Research, 17 (4), 384-391.

Benner, C., Giusta, G., McGranahan, G., Pastor, M. with Chaudhuri, B., Turok, I. \& Visagie, J. (2018). Creating More Inclusive Economies: Conceptual, Measurement and Process Dimensions. Draft paper (March) for the Rockefeller Foundation, New York.

Binns, J.A., \& Nel, E. (2002). Tourism as a Local Development Strategy in South Africa. Geographical Journal, 168 (3), 211-223.

Butler, G., \& Rogerson, C.M. (2016). Inclusive Local Tourism Development in South Africa: Evidence From Dullstroom. Local Economy, 31 (1/2), 264-281.

Donaldson, R. (2007). Tourism in Small Town South Africa. In: C.M. Rogerson and G. Visser (eds.), Urban Tourism in the Developing World: The South African Experience, New Brunswick, N.J.: Transaction Press, 307-325.

Donaldson, R. (2018). Small Town Tourism in South Africa. Cham: Springer International.

Donaldson, R., \& Marais L. eds. (2012). Small Town Geographies in Africa: Experiences from South Africa and elsewhere. New York: Nova Publishers.

Ferreira, S. (2007). Role of Tourism and Place Identity in the Development of Small Towns in the Western Cape, South Africa. Urban Forum, 18 (3), 191-209.

Findlay, K.P. (1997). Attitudes and Expenditures of Whale Watchers in Hermanus. South African Journal of Wildlife Research, 27 (2), 57-62.

Halseth, G., Meikeljohn, C. (2009). Indicators of Small Town Tourism Development Potential: The Case of Fouriesburg, South Africa. Urban Forum, 20, 293-317.

Hampton, M., Jeyacheya, J., \& Long, P.H. (2018). Can Tourism Promote Inclusive Growth? Supply Chains, Ownership, and Employment in Ha Long Bay, Vietnam. Journal of Development Studies, 54 (2), 359-376.

Harmer, D., \& Rogerson, J.M. (2016). Youth Tourism Festivals in South Africa: The Case of Plett Rage. African Journal of Hospitality, Tourism and Leisure, 5 (4), 1-14.

Hunt, B. (2017). Hermanus - Whales, Wine, Fynbos, Art. Cape Town: Penguin Random House.

Irvine, P., Keep, T., de Wet, D., Hamunime, N. (2016). Whose Mecca? Divergent Experiences of Post-productivism and Tourism in Nieu Bethesda, South Africa. South African Geographical Journal, 98 (2), 386-401.

Kontsiwe, N.P. (2018). Tourism - A Vehicle for Local Economic Development in Aliwal North, Eastern Cape. Masters in Development Studies, University of Free State, Bloemfontein.

Lawrence, F., \& Rogerson, C.M. (2018). Local Economic Development Agencies and Place-based Development: Evidence from South Africa. Bulletin of Geography: Socio-Economic Series, 41, 29-43. 
Tourism, Local Economic Development and Inclusion:

Evidence from Overstrand Local Municipality, South Africa

Lawrence, F., \& Rogerson, C.M. (2019). Local Economic Development Agencies and Peripheral Small Town Development: Evidence from Somerset East, South Africa. Urbani izziv, 30, (Supplement), 144-157.

Lee, R. (2017). A History of the New Harbour Hermanus: 1896 to 2016. Unpublished manuscript, Hermanus Historical Society, Hermanus.

Lloyd, F. (2018). Cape Whale Coast: A Tourism Marketing Strategy 2018-2022. Report prepared for Overstrand Local Municipality, Hermanus.

Lourens, M. (2007). Route Tourism: A Roadmap for Successful Destinations and Local Economic Development. Development Southern Africa, 24 (3), 475-490.

Marais, L. (2004). From Small Town to Tourism Mecca: The Clarens Fairy Tale. In C.M. Rogerson \& G. Visser (eds.), Tourism and Development Issues in Contemporary South Africa, Pretoria: Africa Institute of South Africa, 420-435.

McKay, T. (2017). The Adventure Tourism Industry of South Africa: Organisation, Space and Structure. PhD dissertation, University of Johannesburg.

Nel, E., \& Rogerson, C.M. (2005). Local Economic Development in the Developing World: The Experience of Southern Africa. New Brunswick NJ and London: Transaction.

Nel, E., \& Rogerson, C.M. (2007). Evolving Local Economic Development Policy and Practice in South Africa with Special Reference to Smaller Urban Centres. Urban Forum, 18 (2), 1-11.

Nel, E., \& Rogerson, C.M. (2016). The Contested Trajectory of Applied Local Economic Development in South Africa. Local Economy, 31 (1-2), 109-123.

Pike, A., \& Rodriguez-Pose, A., Tomaney, J. (2006). Local and Regional Development. London: Routledge.

Pike, A., \& Rodriguez-Pose, A., Tomaney, J. (2011). Introduction. In A. Pike, A. Rodriguez-Pose and J. Tomaney (eds.), Handbook of Local and Regional Development, London: Routledge, 1-14.

Pike, A., Rodriguez-Pose, A., \& Tomaney, J. (2014). Local and Regional Development in the Global North and South. Progress in Development Studies, 14 (1), 21-30.

Pike, A., Rodriguez-Pose, A., \& Tomaney, J. eds. (2015). Local and Regional Development, 4 Vols. London: Routledge.

PricewaterhouseCoopers (2010). Baseline Impact Assessment: The Impact of Tourism on the Overstrand Economy. Report prepared for the Overstrand Local Municipality, Hermanus.

Rodriguez-Pose, A., \& Tijmstra, S. (2007). Local Economic Development in Sub-Saharan Africa. Environment and Planning C: Government and Policy, 25, 516-536.

Rodriguez-Pose, A., \& Tijmstra, S. (2009). On the Emergence and Significance of Local Economic Development Strategies, Caracas, Venezuela: Financiando El Desarrollo, CAF Working Paper, No 2009/07.

Rodriguez-Pose, A. \& Wilkie, C. (2015). Conceptualising Equitable Economic Growth in Cities, Brussels: Cities Alliance.

Rodriguez-Pose, A., \& Wilkie, C. (2017). Revamping Local and Regional Development Through Place-Based Strategies. Cityscape: A Journal of Policy Development and Research, 19 (1), 151-170.

Rogerson, C.M. (2002a). Tourism and Local Economic Development: The Case of the Highlands Meander. Development Southern Africa, 19, 143-166.

Rogerson, C.M. (2002b). Tourism-Led Local Economic Development: The South African Experience. Urban Forum, 13, 95-119.

Rogerson, C.M. (2006). Pro-poor Local Economic Development in South Africa: The Role of Pro-Poor Tourism. Local Environment, 11, 37-60.

Rogerson, C.M. (2007a). Tourism Routes as Vehicles for Local Economic Development in South Africa: The Example of the Magaliesberg Meander. Urban Forum, 18 (2), 49-68.

Rogerson, C.M. (2007b). Supporting Small Firm Development in Tourism: South Africa's Tourism Enterprise Programme. International Journal of Entrepreneurship and Innovation, 8 (1), 6-14.

Rogerson, C.M. (2010). Local Economic Development in South Africa: Key Strategic Challenges. Development Southern Africa, 27, 481-495.

Rogerson, C.M. (2014). Reframing Place-based Economic Development in South Africa: The Example of Local Economic Development. Bulletin of Geography: Socio-Economic Series, 24, 203-218.

Rogerson, C.M. (2016). Outside the Cities: Tourism Pathways in South Africa's Small Towns and Rural Areas. African Journal of Hospitality, Tourism and Leisure, 5 (3), 1-16.

Rogerson, C.M. (2017). Business Incubation for Tourism SMME Development: International and South African experience. African Journal of Hospitality, Tourism and Leisure, 6 (2). 1-12.

Rogerson, C.M. (2018a). Innovation-Driven Local Economic Development: In Search of Best Practice Implementation for South Africa. Euroeconomica, 37, 15-28.

Rogerson, C.M. (2018b). Urban Tourism, Aerotropolis and Local Economic Development Planning: O.R. Tambo International Airport, Ekurhuleni, South Africa. Miscellanea Geographica - Regional Studies on Development, 22 (3), 123-129.

Rogerson, C.M. (2019). Revamping Local Economic Development Policy in South Africa. In: J. Knight and C.M. Rogerson (eds.) Geography of South Africa: Contemporary Changes and New Directions, Cham: Springer International, 253-259. 
Rogerson, C.M., \& Nel, E. (2016). Planning for Local Economic Development in Spaces of Despair: Key Trends in South Africa's Distressed Areas. Local Economy, 31 (1-2), 124-141.

Rogerson, C.M., \& Rogerson, J.M. (2010). Local Economic Development in Africa: Global Context and Research Directions, Development Southern Africa, 27, 465-480.

Rogerson, C.M., \& Rogerson, J.M. (2014). Agritourism and Local Economic Development in South Africa. Bulletin of Geography: Socio-Economic Series, 26, 93-106.

Rogerson, C.M. \& Rogerson, J.M. (2019). Emergent Planning for South Africa's Blue economy: Evidence from Coastal and Marine Tourism. Urbani izziv, 30 (Supplement), 24-36.

Rogerson, J.M. (2018). The Geography of Tourist Bednights in South Africa. GeoJournal of Tourism and Geosites. 3 (23), 835-847.

Rogerson, J.M., \& Harmer, D. (2015). A 'Rite of Passage' Youth Festival in South Africa: The Origins, Attendees and Organization of Matric Vac. Nordic Journal of African Studies, 24 (3-4), 221-240.

Saarinen, J., \& Rogerson, C.M. (2014). Tourism and the Millennium Development Goals: Perspectives beyond 2015. Tourism Geographies, 16 (1), 23-30.

Saarinen, J., Rogerson C.M., \& Manwa, H., eds. (2013) Tourism and the Millennium Development Goals. Abingdon: Routledge.

Saarinen, J., Rogerson, C.M., \& Hall, C.M. (2017). Geographies of Tourism Development and Planning. Tourism Geographies, 19 (3), 307-317.

Scheyvens, R., \& Biddulph, R. (2018). Inclusive Tourism Development. Tourism Geographies, 20 (4), 589-609.

Steyn, D.W. (2018a). Businesses in Crisis as Protests Continue. The Village News, 29 May-4 June.

Steyn, D.W. (2018b). Planned March Called Off After Negotiations. The Village News, 15-21 May.

Steyn, D.W. (2018c). Progress Made with Housing Issues. The Village News, 12-18 June.

Steyn, D.W. (2018d). The Times They Are a Changin. The Village News, 22-28 May.

Steyn, D.W. (2018e). Housing Issues: Is There Light at the End of the Tunnel? The Village News, 5 September.

Steyn, D.W. (2018f). The Time to Rebuild is Now. The Village News, 29 August.

Steyn, D.W. (2018g). Tourism Sets Its sights on Growth. The Village News, 26 June.

Steyn, D.W. (2018h). New Overstrand Demands. The Village News, 7 November.

Steyn, D.W., da Silva, R. (2018). All at the Ready for Whale Festival. The Village News, 26 September.

Tredgold, A. (1980). Village of the Sea: The Story of Hermanus. Cape Town: Human \& Rousseau.

Van der Merwe, C., \& Rogerson, C.M. (2018). The Local Development Challenges of Industrial Heritage Tourism in the Developing World: Evidence from Cullinan, South Africa. GeoJournal of Tourism and Geosites, 21 (1), 186-199.

*** Anon. (no date [2017]). Feasibility Study for the David Bewster Overstrand Eco-Tourism Farm and Trail Initiative. Report prepared for Overstrand Local Municipality, Hermanus.

***Department of Tourism (2018a). National Tourism Sector Strategy 2016-2026. Pretoria: Department of Tourism.

*** Department of Tourism (2018b). Baseline Study on the State of Transformation in the Tourism Sector. Pretoria: Department of Tourism.

*** Overstrand Aquaculture Consortium (2008). Final Report on the Technical Viability and Opportunities for Aquaculture Development in the Overstrand municipal area. Report prepared for Overstrand Local Municipality, Hermanus.

*** Overstrand Local Municipality (2012). Integrated Development Plan 2012-2017. Hermanus: Overstrand Local Municipality.

*** Overstrand Local Municipality (2014). Area profile for Greater Hermanus (Wards 3, 4, 5, 6, 7, 8, 12, 13) 2013/14. Internal Report, Overstrand Local Municipality.

*** Overstrand Local Municipality (2018a). Integrated Development Plan: 1st Review of 5 Year IDP (2018/19). Hermanus: Overstrand Local Municipality.

*** Overstrand Local Municipality (2018b). Minutes of Economic Development \& Tourism Portfolio Committee. Internal Report, Overstrand Local Municipality.

*** UNWTO (2018). Global Report on Inclusive Tourism Destinations. Madrid: UNWTO.

*** Western Cape Government (2017). Socio-Economic Profile: Overstrand Municipality, 2017. Cape Town, Western Cape Province.

*** Withers Environmental Consultants and Urban Dynamics, Western Cape (2017). Integrated Management Plan for the Fernkloof Nature Reserve, Hermanus. Report prepared for Overstrand Local Municipality, Hermanus.

*** World Bank (2018). An Incomplete Transition: Overcoming the Legacy of Exclusion in South Africa. Washington DC: The World Bank Report No. 125838-ZA.

Submitted:

10.10.2018
Revised:

05.04.2019
Accepted and published online 08.04.2019 